\title{
A transição da comunicação corporativa: possibilidade de participação nas mídias organizacionais*
}

\author{
Arquimedes Pessoni** \\ Kallyny Melina Thomé Portugal****
}

\section{Resumo}

O presente artigo investiga como as formas de comunicação participativa - que preveem a colaboração dos receptores - presentes no mundo midiático do século 21 estão sendo utilizadas no âmbito da comunicação organizacional. Foram observados três canais de comunicação de três empresas: Parceiro-repórter (Odebrecht), Jornal Interagindo (Catuaí Shopping Londrina) e TV Bunge (Bunge), destacados pela Aberje - Associação Brasileira de Comunicação Empresarial - por iniciativas no segmento de comunicação participativa no âmbito empresarial. Os resultados indicam que dentro das organizações, existe a possibilidade de comunicação colaborativa, naquele modelo de comunicação consentida e que não interfira no dia-a-dia da empresa, que prejudique sua imagem ou compartilhe informações privilegiadas que possa comprometer a competitividade da empresa no mercado.

Palavras-chave: Comunicação organizacional. Comunicação participativa. Comunicação empresarial. Cultura organizacional. Participação.

\footnotetext{
* Artigo resultante da dissertação de mestrado da autora Kallyny Melina Thomé Portugal, intitulada "O colaborador como produtor de informação: Possibilidades de transposição de formas de comunicação participativa para as mídias organizacionais". Defendida e aprovada em 16 de dezembro de 2010.

** Professor do Programa de Mestrado em Comunicação Social, Pró-Reitoria de Pós-Graduação e Pesquisa da Universidade Municipal de São Caetano do Sul. São Caetano do Sul-SP, Brasil. Jornalista. Doutor em Comunicação pela Universidade Metodista de São Paulo. Tem artigos publicados em várias coletâneas e revistas científicas. E-mail: pessoni@uscs.edu.br

*** Mestre pelo Programa de Mestrado em Comunicação Social, Pró-Reitoria de Pós-Graduação e Pesquisa da Universidade Municipal de São Caetano do Sul. São Caetano do Sul-SP, Brasil. Jornalista. E-mail: kallynyportugal@yahoo.com.br
} 


\section{The transition of corporate at communication: the possibility of participation in the media organizational}

\section{Abstract}

This article aims to investigate how the participative communication forms - (the ones that predict the collaboration of the receptors) - presents in the $21^{\text {st }}$ century media world have been used in the organizational communication ambiance. The authors observed three communication channels from three companies: Parceiro-Repórter (Odebrecht), Jornal Interagindo (Catuaí Shopping Londrina) and TV Bunge (Bunge) awarded by Aberje - Brazilian Association of Business Communication - for initiatives in the communications segment within participatory business. The results indicate that within organizations, there is the possibility of collaborative communication, communication model that consent and does not interfere in day-to-day business, which negatively affects their image or share privileged information that could compromise the company's competitiveness in the market.

Keywords: Organizational communication. Participatory communication. Business communication. Organizational cultura. Participation.

\section{La transición de la comunicación corporativa: posible participación en los medios de comunicación organizacional \\ Resumen}

El objetivo del artículo es averiguar cómo las formas de comunicación participativa - las que presuponen la colaboración de los receptores - notable en el mundo de la media del siglo XXI son utilizadas en las empresas. Fueran observados tres canales de comunicación de tres empresas: Parceiro-repórter (Odebrecht), Jornal Interagindo (Catuaí Shopping Londrina) e TV Bunge (Bunge) otorgado por Aberje - Asociación Brasileña de Comunicación Empresarial - para iniciativas en el segmento de las comunicaciones dentro de la participación negocio. Los resultados indican que dentro de las organizaciones, existe la posibilidad de comunicación colaborativa, modelo de comunicación que el consentimiento y no interfiere en el negocio del día a día, lo que afecta negativamente a su imagen o compartir información privilegiada que podría poner en peligro la competitividad de la empresa en el mercado.

Palabras clave: Comunicación organizacional. Comunicación participativa. Comunicación empresarial. Cultura de la organización. Participación.

\section{Introdução}

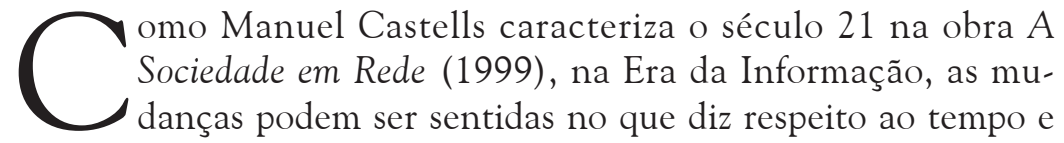


espaço, e na própria relação do receptor com os meios de comunicação (e do modelo tradicional emissor-mensagem-receptor).

A formação de uma consciência coletiva, a mobilização de grupos descontentes, a divulgação rápida de assuntos facilmente escondidos foram propiciadas pelas novas tecnologias. Com o passar do tempo essa manifestação do receptor das informações vem se intensificando gradativamente.

Pesquisadores que trabalham com o conceito de inovação, como Mônica Caprino, Regina Rossetti e Elias Goulart (2008, p.85), destacam que "embora o modo informacional do mundo moderno teoricamente uniformize os receptores da comunicação, sua face tecnológica também lhes dá possibilidade de modificar a relação produtor-receptor da informação".

Os veículos de comunicação tradicional já assumiram essa necessidade de considerar o receptor na comunicação da atualidade. Segundo os mesmos autores (2008, p.85), "os meios de comunicação interferem na forma como definimos a nós mesmos e as nossas relações”. Para Maffesoli (2004, p.23), “[...] as pessoas não querem só informação na mídia, mas também, e fundamentalmente, ver-se, ouvir- se, participar, contar o próprio cotidiano para si mesmas e para aqueles com quem convivem. A informação serve de cimento social [...]".

O objetivo do presente estudo foi investigar como as formas de comunicação participativa - que preveem a colaboração dos receptores - presentes no mundo midiático do século 21 estão sendo utilizadas no âmbito da comunicação organizacional. Trata-se de estudo exploratório, utilizando a análise documental de produtos jornalísticos voltados ao público interno de três empresas (Odebrecht, Catuaí Shopping Londrina e Bunge) destacados pela Aberje - Associação Brasileira de Comunicação Empresarial - por iniciativas no segmento de comunicação participativa no âmbito empresarial. Além da análise do conteúdo dos produtos jornalísticos dessas empresas, foram realizadas entrevistas semiestruturadas com responsáveis pela comunicação nas referidas empresas.

Adotamos os termos comunicação organizacional, comunicação empresarial e comunicação corporativa como sinônimos, embora alguns autores defendam diferenças (mesmo que peque- 
nas) entre elas. Utilizamos, também, a terminologia comunicação participativa para designar essa mudança no perfil do receptor de comunicação, que passou a agir, no século 21, como um produtor de informação, termo defendido pelos autores Shayne Bowman y Chris Willis (2003, p.22-33), que destacam que as formas de participação do público podem ser por meio de grupos de discussão; conteúdos gerados por usuários por meio de três vias, e-mail, classificação das notícias (de um jornalista ou outros usuários) e sistemas de retroalimentação (enquetes, por exemplo); weblogs (com publicação colaborativa e em grupo). Reforçamos, assim, e de acordo com os autores, que as atividades que os usuários podem realizar a partir dessas ferramentas interativas vão desde o comentário, filtro, edição até reportagens ou emissões de áudio e vídeo. Portanto, ao falarmos em comunicação participativa a partir da web (o webjornalismo), defendido por Primo e Träsel (2006, p.9) e Virginia Fonseca e Cristiane Lindemann (2007, p.88), utilizaremos as mesmas definições do jornalismo participativo, embora o webjornalismo remeta à ideia de produção e publicação de notícias na rede mundial de computadores a partir de qualquer usuário, como uma prática jornalística aberta a todos.

\section{Comunicação participativa}

No jornalismo, independentemente do formato de mídia a ser utilizado, passa-se a inserir nas reportagens e notícias contextos vividos pelo receptor no cotidiano, permitindo a ele posicionar-se sobre os assuntos por meio das tradicionais cartas aos leitores, ligações para os veículos de comunicação, contatos via e-mail, posts em blogs, ou alguma outra ferramenta das chamadas redes sociais.

Neste cenário de emergência do cidadão como protagonista e produtor de conteúdos (ele comenta, critica e se faz ouvir), estão inseridas também as organizações, formadas por profissionais que interagem com o mundo exterior a elas, ideia corroborada pelas autoras Maria Inês Tomaél, Adriana Rosecler Alcará e Ivone Guerreiro Di Chiara (2005, p.103): 
[...] As organizações são formadas por pessoas que, por sua vez, são pontos (nós) das redes sociais e detentoras do conhecimento e das habilidades. Quando compartilhados (conhecimento e habilidades) transformam-se em aprendizagem organizacional, que resulta na acumulação de novos conhecimentos e, consequentemente, impulsiona as inovações [...].

Ao falar em comunicação dentro das organizações, estamos tratando da comunicação interna, que se torna relevante quando se debate a comunicação corporativa, afinal, ela influencia, queiram as empresas ou não, nos próprios resultados da corporação. Ou seja, para os empregados (conhecidos também como colaboradores) serem motivados a trabalhar pelas metas da organização e se tornarem aliados poderosos das empresas, eles precisam se sentir parte daquela corporação e sentir que isso faz diferença para o líder do seu setor ou de qualquer outro. Empresas que se descuidam da sua comunicação interna podem ter nos empregados o que especialistas no setor consideram por "embaixadores da indiferença”. Um público desmotivado indica perda de rendimento; se não produz, a empresa tem prejuízos.

Segundo James Collins e Jerry Porras (1995, p.78): “estudos demonstram que organizações internamente desalinhadas se mostram mais frágeis diante do ambiente competitivo do que as organizações que contam com uma resposta rápida e uníssona dos seus empregados". E complementam que a valorização dos indivíduos, bem como sua participação no processo organizacional, é um componente estratégico para a competitividade das organizações, não apenas uma consequência. Afinal, lida com o coração de uma organização, a sua força pensante, o trabalhador. É esse trabalhador, inclusive, o receptor da comunicação na empresa, devendo ser considerado no processo comunicacional. "A participação parece ser a chave para entender o sucesso de iniciativas de organizações de respostas do público". ${ }^{1}$ (DEUZE; BRUNS; NEUBERGER, 2007, p.327).

Por esse motivo, a pesquisa desenvolvida (e apresentada em parte neste artigo) apresenta caráter inovador porque trata o receptor

\footnotetext{
${ }^{1}$ Participation seems to be key for understanding the success of both the industry initiative and the community's response.
} 
da comunicação interna da empresa como um possível participante e/ou emissor de informação e conteúdo, relacionando, assim, as transformações ocorridas na sociedade e na comunicação com aquelas do ambiente organizacional, que também teve que mudar e se adaptar a algumas imposições do mercado global.

\section{A participação do público no processo de comunicação}

Diante desse cenário, o do jornalismo 3.0., não só a produção de veículos próprios, como blogs e podcasts, tem permitido ao consumidor se tornar produtor de informação, mas também os meios de comunicação tradicionais vêm abrindo espaço (ao longo da história) para a participação do público. Um impresso possui um canal de notícias na internet, aceita fotos de pessoas comuns (como o "FotoRepórter" do jornal O Estado de S.Paulo), ou seja, interage com os receptores. Logo, segundo Mielniczuk e Silveira (2008, p.173), "além de pautar as discussões na sociedade, o jornal agora também convida o leitor a participar da produção das notícias".

Links para "cidadãos repórter" enviarem seus flagras espalhamse nos sites de notícia e de veículos jornalísticos, de acordo com Lidiane Amorim (2010, p.3).

[...] Jornalistas, leitores, internautas, interagem como nunca antes e as notícias saem das redomas dos profissionais de comunicação e passam a receber a intervenção de cidadãos comuns. Além de quantitativa, a participação de cidadãos na produção de notícias também sofreu um salto qualitativo na medida em que o formato e a qualidade das mensagens e intervenções foram sendo transformadas na mesma velocidade em que as tecnologias de informação e comunicação avançam [...]

Segundo Fabio Malini (2008, p.11), os veículos criaram "canais de jornalismo cidadão”, uma forma de trazer os conteúdos circunscritos a blogs e sites independentes, que, com frequência, geram audiência e complementam as informações dos jornais online. $\mathrm{O}$ usuário, para colaborar com as informações (em qualquer formato) é avisado de que "para enviar material, deverá concordar com o Termo de Compromisso e Cessão de Direitos Autorais”. 
Lemos (1997) observa que essa mídia tradicional (jornal, revista, rádio, televisão) impunha uma passividade ao público e uma pré-escolha das informações que seriam transmitidas, o que muda com as tecnologias digitais, que alteram a forma de circulação de informações. Passa-se do modelo "um para todos" ao "todos para todos", que constitui uma forma descentralizada e universal de circulação de informações.

\section{O funcionário como produtor de conteúdo: o colaborador- repórter}

Diante dos modelos de participação do receptor (como produtor de informação) na mídia tradicional, e as ferramentas que possibilitam essa participação na comunicação das organizações, é possível observar cases de empresas (de diversos segmentos) que exemplificam essa nova postura do receptor do século XXI no âmbito corporativo.

Empresas como Telefônica, Coca-Cola e Petrobras, por exemplo, investem nas mídias sociais para falar com seus públicos de interesse. A Telefônica fez um monitoramento nas redes sociais para descobrir quais as demandas em relação aos serviços prestados pela companhia. Dirigiu-se, especificamente, aos consumidores, o que a permitiu se aproximar deles e minimizar os problemas. A Coca-Cola realizou uma ação promocional de Dia das Mães pelo Twitter, logo só participaram pessoas com perfil ativo nessa ferramenta. E a Petrobras realizou uma palestra virtual por meio do Second Life, uma comunidade virtual em 3 D (três dimensões), em que os usuários, para participar, se cadastravam na rede e passavam a ter avatares (representações virtuais).

No entanto, embora existam casos que envolvem a participação do colaborador como produtor de informação nos veículos de comunicação das empresas (estamos colocando, neste cesto, todos os meios disponíveis para comunicação interna nas organizações), a realidade, de uma forma geral, mostra-se, ainda, incipiente. Os casos exemplificados nesta pesquisa indicam iniciativas de organizações para inserir seus funcionários (os colaboradores) como atuantes no processo de comunicação. 


\section{Os exemplos de comunicação participativa: Parceiro-repórter, Jornal Interagindo e TV Bunge}

A Odebrecht criou em sua revista eletrônica (a Odebrecht Informa Online), hospedada dentro do website da companhia (destinado também ao público externo) um canal intitulado "Parceiro-repórter", em que os funcionários eram chamados a produzir e enviar vídeos para a empresa, em formatos especificados em um termo de compromisso disponibilizado para download no próprio site. Eram disponibilizados, também, os contatos com o editor desse canal. Segundo a responsável pela área de publicações na Odebrecht, Karolina Gutiez, a iniciativa do projeto era transformar os colaboradores em "repórteres de TV". No início de 2010, no entanto, segundo o departamento de comunicação da empresa, o projeto foi suspenso, pois não houve adesão por parte dos funcionários.

O Catuaí Shopping Londrina (PR) teve a iniciativa de inserir os lojistas e funcionários, no caso, seu público interno, em um dos veículos internos de comunicação da organização, o Jornal Interagindo. São cerca de mil exemplares, distribuídos mensalmente, que divulgam as ações tanto da administração quanto dos próprios lojistas, que podem contribuir para incrementar as notícias do veículo, por meio de sugestões de pautas ou produção de conteúdo. O case foi premiado pela Aberje região Sul.

A Bunge foi pioneira nesse tipo de iniciativa no Brasil ao incluir o funcionário na produção de uma TV corporativa, a TV Bunge. Desde 2001, a Bunge aposta em soluções em vídeo para conversar com os colaboradores. Em 2005, a iniciativa da TV Bunge foi destacada pelo Prêmio Aberje São Paulo. Segundo Valdeci Roberto Silva, coordenador da área de comunicação da Bunge, a ideia de colocar o colaborador na frente das câmeras não deu tão certo quanto o esperado. "Percebíamos que nem todo mundo tem facilidade para falar para a câmera, com equipe de gravação, e os colaboradores escolhidos ficavam pouco à vontade" ${ }^{2}$. No entanto, os funcionários continuam participando da TV Bunge, de forma

\footnotetext{
${ }^{2}$ (Entrevista dada à Revista Aberje - Comunicação Empresarial, de 2009 - ano 19, n. 72)
} 
mais informal, geralmente como fontes de entrevistas ou o que a Bunge chama de "reportagens de rua", estimulando os funcionários a contarem sobre suas vidas sem constrangimento.

\section{Análise e considerações finais}

Dinâmica e inquieta, a comunicação precisa ser vista como um conjunto em movimento, em que, ao mudar o tempo, mudam-se também os meios e as formas de comunicar. E essas mudanças são proporcionadas pelas possibilidades cada vez maiores de participação dos receptores junto aos meios e às mensagens. No sistema comunicacional do século 21, ou Era da Informação (conceito trabalhado principalmente por Castells) ou, ainda, Era da Participação, o receptor não pode ser desconsiderado.

No jornalismo, como já destacado, independente do formato de mídia a ser utilizado, passa-se a inserir nas reportagens e notícias contextos vividos pelo receptor no cotidiano, permitindo a ele se posicionar sobre os assuntos por meio das tradicionais cartas aos leitores, ligações para os veículos de comunicação, contato via e-mail, posts em blogs, ou alguma outra ferramenta das chamadas redes sociais.

É neste cenário de emergência do cidadão como protagonista e produtor de conteúdos, de acesso às tecnologias de comunicação e informação, em que estão inseridas também as organizações, formadas por profissionais que interagem com o mundo exterior a elas.

Nada mais esperado do que imaginar que essas empresas estejam preocupadas em inserir seus colaboradores (e a si próprias) nessa atmosfera participativa, sendo pouco provável a defesa do autoritarismo nessa sociedade conectada. Isso é o que se pode inferir a partir da discussão trazida pela revisão bibliográfica e com base nas entrevistas complementares realizadas junto a especialistas em comunicação organizacional e novas mídias.

Para a análise, consideramos as características desenvolvidas para atender às demandas desse novo receptor identificadas na etapa de revisão bibliográfica. Logo, foi observado se existe filtro de informação, como ele é feito, quem o faz, se existe restrição quanto a temas e assuntos a serem abordados; como os funcioná- 
rios são selecionados a participar; quais as formas de participação disponíveis aos funcionários (produção de conteúdo? participação em coluna? foto? reunião de pauta? conselho editorial e/ ou comitê de comunicação? envio de sugestões? apenas fonte?); se existe comunicação com o funcionário após sua participação (independente de sua produção ser aceita ou não); existência de termos de compromisso ou regulamento com as políticas internas a serem seguidas; definição do grau de participação e autonomia junto às mídias sociais.

Antes de observar os veículos de comunicação e seus formatos, é fundamental entender de onde partem as iniciativas de comunicação (justificaria, assim, por exemplo, opções por determinados veículos em detrimento a outros) e as formas como são elaboradas e executadas. Para isso, observa-se que o caminho, nas organizações modernas, é a comunicação integrada (que pressupõe uma integração entre áreas diretamente ligadas à comunicação - Comunicação Corporativa/Organizacional, Marketing, Comunicação Interna), que assegura a completa caracterização dos públicos, bem como suas demandas informativas, afinal, no caso da comunicação interna, para assegurar que os funcionários sejam os "embaixadores” da organização, é necessário que eles sejam verdadeiros multiplicadores dos valores, atividades e produtos da empresa; que eles estejam sempre bem informados. O público interno é um dos que tem maior crédito ao falar a respeito da organização.

Nas empresas analisadas, nota-se o envolvimento de diversos departamentos neste processo, estando estes subordinados a algum outro que trate de assuntos corporativos, institucionais ou, ainda, ao marketing, tendo em vista que muitas organizações, hoje, ainda nomeiam a área de comunicação (apenas) como marketing. $\mathrm{Ou}$, ainda, seus profissionais responsáveis por cuidar, por exemplo, de veículos institucionais. É o caso do Catuaí Shopping Londrina, que coloca seus veículos internos, especificamente o Jornal Interagindo, sob a orientação da analista de marketing.

A primeira curiosidade à qual se fazia necessário responder na pesquisa era: como as organizações estão se posicionando internamente frente a esse receptor/produtor de informação? Existem, na realidade, iniciativas e tentativas de trabalhar (e entender) o 
público interno como um agente produtor de informação dentro das empresas. O fato de essas experiências existirem, por si só, já indicam uma mudança (mesmo que leve!) do pensamento burocrático corporativo. O número de experiências ainda é pequeno (tendo em vista o tamanho e o número de empresas existentes), mas o ponto positivo é que vêm se multiplicando ao redor do mundo. Com a mídia tradicional também foi assim.

Os dados da pesquisa com as três organizações - Bunge, Odebrecht e Catuaí Shopping Londrina - sugerem que, apesar de as organizações estarem inseridas neste cenário de crescente participação do receptor, essa participação do antes consumidor de informação como produtor de conteúdo não se revela uma tendência no mundo organizacional, por mais que os profissionais da área, como os entrevistados neste projeto, indiquem formas de tornar isso possível.

Significaria dizer que as organizações teriam muito a ganhar com uma comunicação, de fato, participativa, não a realizada hoje puramente para sugerir à sociedade e ao mercado que ela seja democrática. Alguns dos itens apontados como positivos: ampliar a perspectiva da organização em relação a determinados temas ou assuntos, estimular a interação e o debate interno (maior envolvimento com os públicos de interesse, rapidez de informação e feedback), incluir novas pautas na agenda da organização, democratização da informação, reforço da auto-estima dos envolvidos e participantes, construção colaborativa do conhecimento, criação de um senso de comunidade, estímulo à criação e incentivo à proatividade, e, sobretudo, sintonia em relação a demandas presentes e futuras do mercado e da sociedade.

Promover a comunicação de mão dupla, portanto, parece ser o desafio das empresas frente ao cenário atual, manifestado na mídia tradicional de uma forma geral. Esses três canais de comunicação foram escolhidos por exemplificar, ao menos um pouco, essa mudança no perfil do receptor dentro das organizações. Os canais da Odebrecht e da Bunge são muito parecidos na concepção: permitir que o colaborador se torne um repórter dentro da empresa. A ideia da Odebrecht era dar autonomia para o colaborador produzir o vídeo que quisesse, com a possibilidade 
de veiculá-lo na edição eletrônica da Revista Odebrecht Informa. Já a Bunge tem como objetivo inserir o colaborador na produção, mas existe um roteiro a ser seguido pelo funcionário, no entanto, é uma forma de participação mais atrativa. No caso do Catuaí Shopping, com o Jornal Interagindo, a intenção é aproximar os lojistas, permitindo-lhes participar, hoje, das pautas, reuniões e dar sugestões. Fica a ressalva de que a ideia mais atrativa seria a inserção de materiais produzidos pelos próprios lojistas nas páginas do jornal, no entanto, o projeto foi postergado. Os projetos do Catuaí Shopping e da Bunge tiveram adesão por parte dos seus públicos de interesse, como mostram, inclusive, os dados de pesquisas internas realizadas pelos departamentos de comunicação das empresas. Ambas as iniciativas foram premiadas pelo Prêmio Aberje (de 2006 e 2005, respectivamente), nas categorias Boletim Interno (Jornal Interagindo) e Vídeo de Comunicação Interna (TV Bunge), respectivamente. O projeto "Parceiro-Repórter", no entanto, foi descontinuado pela Odebrecht, mas mereceu destaque na edição número 72 da Revista Comunicação Empresarial, de 2009.

Foi possível perceber, por meio da pesquisa, que existe uma tentativa por parte das organizações de analisar o colaborador pelo desempenho, seja nas atividades diárias, seja em atividades extra ou concursos. No entanto, o que é comum a todas as empresas (considerando, obviamente, a revisão bibliográfica, a opinião dos especialistas e as três empresas observadas) é o programa de incentivos como a principal ferramenta para valorização dos colaboradores, um pensamento um tanto burocrático, pois não significa dizer que esses funcionários se sintam parte da organização ou que atuem como os “embaixadores". A observação das políticas de comunicação interna de uma organização (aliado à sua cultura organizacional) permite inferir sobre seu posicionamento frente às tendências comunicacionais apresentadas pela mídia tradicional fora das organizações, como a mudança na relação emissor-receptor, justificando, assim, inclusive, a busca por inserção do público interno nas atividades da empresa, que culminariam em reconhecimento deste e de seus pares, gerando, assim, um sentimento de valorização por parte deste. É como se os proces- 
sos efetivos de interação permanecessem ocultos, confirmando as proposições apresentadas no início dos estudos.

A segunda curiosidade estava em identificar quais as formas de participação disponíveis aos funcionários nas organizações, em contraponto às possibilidades existentes (para a participação do receptor) na mídia tradicional. Pôde-se observar, com base na revisão bibliográfica e nas entrevistas com os gestores de comunicação das três organizações observadas, que existe produção de conteúdo (mesmo que supervisionado ou direcionado por especialistas), participação em reunião de pauta, comitê de comunicação e feedback, como fonte de informação (em alguns casos, apenas desse modo) e notícia. Esta prática mostrou ser a mais recorrente no ambiente organizacional. Nota-se que a Bunge e a Odebrecht optaram por inserir seus colaboradores em produções televisiva e digital, enquanto o Catuaí Shopping Londrina optou por fazê-lo em um dos meios mais tradicionais (tanto fora quanto dentro das organizações), a mídia impressa, que ainda parece ser uma das apostas de boa parte de organizações no relacionamento com seus públicos internos.

Observa-se, portanto, que os funcionários poderiam participar do processo comunicacional da empresa de algumas formas, sem necessariamente serem invasivos. Algumas das sugestões para isso seriam: novos temas para debate, atuando como fonte para determinados temas, assinando colunas ou artigos, conhecendo os objetivos da organização, participando previamente de reuniões temáticas, sendo incentivado de fato a participar, tendo apoio de suas chefias para este envolvimento, através de fóruns, blogs, wikis.

A partir dos projetos das organizações, nota-se que existe uma consciência de que há necessidade do relacionamento de mão dupla na comunicação da empresa e em todo o processo de gestão. Todas as ferramentas que estiverem à disposição do colaborador podem contribuir para estreitar o relacionamento e valorizar esse funcionário cada vez mais como um receptor produtor de informação. Teoricamente, todos os canais de comunicação que estiverem a serviço do funcionário serão regidos por algum setor/departamento específico (com algumas exceções, como a chamada "Rádio-Peão"). No entanto, é importante que 
os colaboradores possam participar ativamente do processo de comunicação. No entanto, esses espaços de participação ainda são muito restritos dentro das organizações. Pode-se inferir, assim, que o que é sugerido na revisão bibliográfica como comunicação interna tradicional, é o que é praticado hoje, nesse século 21, nas organizações. Portanto, as formas de participação disponíveis aos receptores no século 21 em diversas mídias dentro das organizações são: revista (impressa e eletrônica), boletim, jornal interno, mural de recados, reuniões.

Historicamente, o uso de determinados veículos ou atividades específicas dentro da organização caracterizam, por si só, sua comunicação interna, fato que contribui para que essa comunicação seja considerada ineficiente em muitos casos, pois quase sempre desconsideram as especificidades de seus públicos, mesmo internamente, afinal as demandas de informação são diferentes e implicam observação, para que não sejam apenas veículos, mas sim verdadeiros canais de comunicação, promovendo a comunicação interna transparente, democrática, ética e que valorize a participação e os diferentes grupos internos de uma organização, como diz Wilson da Costa Bueno (2010)3. Das organizações analisadas, é possível perceber essa preocupação em trazer o colaborador para perto da empresa, pois existem diversas iniciativas de comunicação, em vários formatos. Nesta lista, entram os casos utilizados para exemplificar nosso objeto de estudo: o jornal Interagindo, do Catuaí Shopping, o Parceiro-Repórter, da Odebrecht, e a TV Bunge. Essas organizações apresentam os canais de comunicação classificados por Sônia Pessoa (2003) em pessoal (como a comunicação face a face ou por meio de correio/telefone, encontros, reuniões, entrevistas, conversas etc.) e impessoal (mensagens expressas a partir da mídia impressa, televisiva, radiofônica, visual, digital).

Com base nas entrevistas realizadas com os responsáveis pelos veículos estudados nesta pesquisa, percebe-se que as empresas ainda não estão se relacionando com seus públicos, sobretudo o interno (alvo dessa pesquisa), por meio das redes sociais, e não

\footnotetext{
${ }^{3}$ Vide depoimento na íntegra na dissertação de mestrado da autora, disponível em: http://www.uscs.edu.br/posstricto/comunicacao/dissertacoes/2011/pdf/dissertacao_completa_kallyny_melina_thome_portugal.pdf.
} 
têm direcionamentos para fazê-lo (justificando, assim, o grau de participação e autonomia junto às mídias sociais, considerado um outro item para analisar as formas de comunicação participativa dentro das empresas). É mais uma forma de "cumprir metas", como defendido pelos especialistas.

Em se tratando de comunicação digital nas organizações, é possível observar diferenças fundamentais entre o cenário $1.0 \mathrm{e}$ 2.0, inclusive para o entendimento dessa mudança não apenas tecnológica, mas também de posicionamento. No cenário 2.0, os públicos podem influenciar (tanto positiva quanto negativamente) uma empresa das mais diversas formas, há uma ruptura do predomínio do polo de emissão; criação de canais de informação e conversação independentes das fontes formais - existe, na realidade, o reconhecimento de um usuário propagador da mensagem para outros grupos de pessoas. No cenário 1.0, as preocupações se encerram com a assimilação da mensagem pelo receptor, com baixa capacidade de personalização do conteúdo. Logo, significa dizer que é "publicado" o que é de interesse da organização, não necessariamente dos seus públicos. Reforço, portanto, a necessidade e importância de uma melhor compreensão e uso das ferramentas disponíveis neste cenário.

O terceiro ponto a ser discorrido é em relação aos "filtros de informação", um elemento característico no sistema comunicacional das organizações do século 21. Como moderadores de participação (ou, em alguns casos, poderiam ser considerados aparelhos censores), estão presentes no formato de termos de compromisso/ adesão ou responsabilidade, manuais de uso/política interna ou de pré-cadastros, em que todas as informações da pessoa ficam registradas em uma base de dados. No caso das organizações, é de esperar que a comunicação aconteça de forma moderada, e, nesse caso, deixa de ser considerada totalmente participativa. Nos três exemplos das três organizações citadas, existe o filtro de informação, feito, em geral, pelo próprio departamento de comunicação ou áreas afins. No caso da Odebrecht, existia (durante o tempo em que o canal esteve disponível no site da organização) um termo de compromisso (que deveria ser preenchido e assinado pelo 
colaborador), um manual de instruções para produção e envio dos vídeos, e um editor disponível através de um e-mail.

Outro ponto que caracterizaria um filtro de informação é em relação aos assuntos de que são permitidos abordar nesses canais de comunicação. Nota-se que, geralmente, existe um direcionamento de todas as pautas por equipes de comunicação, que, como já relatado, se encarregam de verificar o tipo de assunto que pode ser produzido pelos colaboradores. Novamente, observa-se a figura dos "censores" no processo de inserção dos colaboradores no processo de produção de informação dentro das organizações. Nota-se, no entanto, a possibilidade de participar, desde que o conteúdo não se apresente na forma de reclamação ou reivindicação.

Além desses "filtros de informação", outra característica que assombra a comunicação interna nas organizações é a autocensura por meio dos próprios colaboradores. Pôde-se observar, mais atentamente, essa característica por meio da análise dos canais de comunicação das três organizações listadas, especificamente de duas - Bunge e Odebrecht. É interessante observar, por exemplo, que desde 2004, o projeto da Bunge teve parte de sua ideia inicial alterada, tendo em vista que os colaboradores se sentiam intimidados em ficar de frente às câmeras, como relatado por Valdeci Silva em reportagem da Revista Comunicação Empresarial - Aberje (Ano 19, número 72, 2009). Diante de tal percepção, o projeto não foi interrompido, mas sim reconfigurado. Hoje, os funcionários servem de fonte e pauta para matérias produzidas por uma equipe de comunicação. No caso do Catuaí Shopping Londrina, o que se observa é que a iniciativa (contemplada pelo Prêmio Aberje em 2006) vem dando certo, pelo menos, existe previsão de continuação e de pequenas (mas muito importantes!) mudanças: os lojistas poderão atuar como produtores de textos do jornal. A Odebrecht, após um ano e seis meses com o projeto no ar, desativou-o este ano (2010), por falta de adesão dos funcionários. Nota-se, aqui, uma reação muito parecida com a dos colaboradores da Bunge, quando do inicio do projeto. Nota-se, na realidade, uma autocensura por parte dos próprios funcionários, que podem ter se sentido inibidos ou desencorajados a participar ativamente da produção de conteúdo nessas organizações. Ao contrário do que fez a Bunge, 
a Odebrecht desativou o projeto "Parceiro-Repórter", deixando, assim, de existir esse espaço destinado, especificamente, à produção do colaborador.

Essa ação (de autocensura) poderia ser justificada por diversos fatores: não há um sentimento de pertencimento por parte dos colaboradores em relação aos programas desenvolvidos pela empresa, elucidando a classificação de Bordenave (2001, p.22) sobre ter parte, tomar parte e fazer parte. Ou seja, nas organizações, o que se observa é que os colaboradores fazem parte do processo comunicacional (porque é uma ação involuntária, logo, não há convite para isso) ou tomam parte em uma ação específica dentro de uma atividade coletiva. No entanto, eles não têm parte nesse processo, justamente por não existir esse sentimento de pertencimento e apropriação.

Outro fator que poderia justificar essa falta de sentimento retratada acima é devido à cultura organizacional. Significa dizer que a partir da cultura de uma empresa (e, junto a ela, a observação das políticas de comunicação interna adotadas, por exemplo) é possível inferir se as demandas de comunicação partem dos funcionários, da organização, do ambiente interno etc.

Nos três canais observados, nota-se que essas demandas partem, sobretudo, da organização ou dos departamentos de comunicação/marketing da empresa, não retratando, necessariamente, desejos dos funcionários ou do ambiente interno de uma forma geral. Neste caso, significa dizer que a ideia é colocada "de cima para baixo", não o inverso, o que justificaria, também, a classificação proposta por Bordenave. Existem casos, no entanto, em que as propostas partem de conversas com colaboradores - seja pelas próprias reuniões de pauta, nas sugestões por comitês de comunicação ou no contato com os chefes -, neste caso não se pode considerar, vias de regra, essa comunicação "de cima para baixo".

No entanto, a partir dos exemplos observados, não é possível compactuar com a ideia levantada pelo referencial teórico de que a forma com que os indivíduos se comunicam pode mudar a cultura que compartilham na organização. Talvez o exemplo mais forte para elucidar esse posicionamento das organizações seja o da Odebrecht. Ao avaliar se a comunicação participativa seria uma 
tendência dentro da empresa, a entrevistada foi veemente em sua justificativa de que "não faz o estilo da empresa". Ao contrário do que foi apresentado durante toda a etapa de revisão bibliográfica, e confrontando a opinião de especialistas em comunicação organizacional e novas mídias, as organizações utilizadas para exemplificar iniciativas de comunicação participativa dentro das empresas parecem não acreditar que ela possa, de fato, acontecer, sem que se torne uma ameaça. Mesmo disponibilizando canais para esse fim. E mesmo tornando públicas suas iniciativas com eles. $\mathrm{O}$ que existe é uma abertura para a sugestão e envio de pautas, mas o controle fica restrito aos departamentos e áreas de comunicação (quando não, os executivos chefes!) da empresa. A Odebrecht, mesmo com um canal intitulado "Parceiro-Repórter" parece ser a mais incrédula em relação a essa tendência que vem se expandindo pelo universo comunicacional, alegando simplesmente não haver abertura para esse tipo de comunicação. De qualquer forma, é válido analisar os argumentos de organizações ativas neste século XXI (a Era da Participação, para alguns autores) quanto às ferramentas de comunicação e posicionamento estratégico para manterem-se competitivas nesta Era tão bem definida por Castells (1999).

O controle da informação pode se manifestar de algumas outras formas dentro das organizações. Já foram citados a censura por meio dos "filtros de informação", dos pré-cadastros e dos termos de responsabilidade, bem como a própria autocensura, observada em alguns dos canais analisados. No caso das redes sociais, permite-se arriscar mais uma forma de moderação da informação: as políticas internas de uso das redes. No caso do Catuaí Shopping Londrina e da Bunge, esse limitador existe, ou seja, o controle está nas mãos de departamentos específicos, geralmente o de comunicação.

Os dados, inferidos a partir da pesquisa, indicam que dentro das organizações, existe a possibilidade de comunicação colaborativa, aquele modelo de comunicação consentida e que não interfira no dia-a-dia da empresa, prejudique sua imagem ou compartilhe informações privilegiadas que possam comprometer a competitividade da empresa no mercado. E essa participação tende a ser feita por e-mail e/ou oralmente; os funcionários que são chamados a participar, geralmente, são por indicação de líderes; não é uma 
colaboração livre, ou seja, existe pelo menos um departamento "fiscalizando" as ações dos funcionários nesses canais teoricamente "participativos".

A partir da análise das três iniciativas de comunicação participativa dentro de organizações, é possível inferir que duas delas deram resultados, mesmo que suscitando, por diversas características, a comunicação colaborativa, como descrevemos anteriormente.

\section{Referências}

ABERJE. Colaborador Repórter - Como no programa de Caco Barcellos, empresas incentivam funcionários a produzir matérias para TV interna. Revista Comunicação Empresarial, a. 19, n. 72. São Paulo, 2009.

AMORIM, Lidiane Ramirez de. Novas formas de ver: (re)significação das notícias de TV a partir do jornalismo participativo. In: XXXIII CONGRESSO BRASILEIRO DE CIÊNCIAS DA COMUNICAÇÃO. Caxias do Sul, RS, 2-6 de setembro de 2010. Anais....

BORDENAVE, Juan E. Diaz. Além dos meios e mensagens: introdução à comunicação como processo, tecnologia, sistema e ciência. Petrópolis: Vozes, 2001.

BOWMAN, Shayne; WILLIS, Chris. Nosotros, el médio: Cómo las audiencias están modelando el futuro de la noticias y la información. The Media Center at The American Press Institute. Traduzido por Guillermo Franco M. Bogotá: Casa Editorial El Tiempo (CEET), 2003. Disponível em: <www. hypergene.net/wemedia/espanol.php>. Acesso em: 30 mar 2009.

BUENO, Wilson da Costa. Entrevista. 2010. Entrevista concedida a Kallyny Melina Thomé Portugal. Realizada por e-mail, 17 set. 2010. Disponível em: http://www.uscs.edu.br/posstricto/comunicacao/dissertacoes/2011/pdf/dissertacao_completa_kallyny melina thome_portugal.pdf. Acesso em: 20 jun.2011.

CAPRINO, Mônica Pegurer; ROSSETTI, Regina; GOULART, Elias. Comunicação e Sociedade: faces e interfaces inovadoras. In: CAPRINO, Mônica Pegurer(Org). Comunicação e inovação: reflexões contemporâneas. São Paulo: Paulus, 2008. p. 83-110.

CASTELLS, Manuel. A sociedade em rede. São Paulo: Paz e Terra, 1999.

COLLINS, James; PORRAS, Jerry. Feitas para durar. Rio de Janeiro: Rocco, 1995. 
DEUZE, Mark; BRUNS, Axel; NEUBERGER, Christoph. Journalism Practice, v. 1, n. 3. UK: Taylor \& Francis Group, 2007.

FONSECA, Virginia; LINDEMANN, Cristiane. Webjornalismo participativo: repensando algumas questões técnicas e teóricas. Revista FAMECOS, n. 34, dez.2007, quadrimestral, p.86-94. Porto Alegre: PUC-RS.

LEMOS, André. Anjos interativos e retribalização do mundo. Sobre interatividade e interfaces digitais, 1997. Disponível em: < http://www.facom.ufba. br/pesq/cyber/lemos/ interac.html>. Acesso em: 10 jun. 2010.

MAFFESOLI, Michel. A comunicação sem fim (teoria pós-moderna da comunicação). In: MARTINS, Francisco M.; SILVA, Juremir M.da. (Orgs). A genealogia do virtual: Comunicação, cultura e tecnologias do imaginário. Porto Alegre: Sulina, 2004.

MALINI, Fabio. Modelos de colaboração nos meios sociais da internet: Uma análise a partir dos portais de jornalismo participativo. In: XXXI Congresso Brasileiro de Ciências da Comunicação. Natal, RN, 2-6 de setembro de 2008. Anais....

MIELNICZUK, Luciana; SILVEIRA, Stefanie Carlan da. Interação mediada por computador e jornalismo participativo nas redes digitais. In: PRIMO, Alex et al.(Orgs.).Comunicação e interações. Porto Alegre: Sulina, 2008.

PESSOA, Sônia. Comunicação Empresarial, uma ferramenta estratégica. Labcom, 2003. Disponível em: < http://www.bocc.ubi.pt/pag/pessoa-soniacomunicacao-empresarial-estrategica.pdf $>$. Acesso em: 10 jun. 2009.

PRIMO, Alex; TRÄSEL, Marcelo. Webjornalismo participativo e a escrita coletiva de notícias. Contracampo, v.14, 1ํㅗ. sem.2006. Niterói: UFF. Disponível em: <http://www6.ufrgs.br/limc/PDFs/webjornal.pdf>. Acesso em: 15 ago. 2009.

TOMAÉL, Maria Inês; ALCARÁ, Adriana R.; CHIARA, Ivone Guerreiro di. Das redes sociais à inovação. Ci. Inf., v. 34, n. 2, maio/ago. 2005, p. 93-104. Brasília. 